総説

地域栄養計 画

豊川裕之

東京大学医学部保健学科

\title{
Community Nutrition Program
}

\author{
Hiroshi TOYOKAWA \\ School of Health Sciences, Faculty of Medicine, University of Tokyo
}

\section{1. はしめに}

地域栄美計画は，「地域」と「栄蛝」の概念をまず明確 にした上で論述されねばならない。

「地城」には area, region, district, community のど れを当てることるできる。しかしそそのどれるが少しず つ異なった概念をもっている。 region には地理学的・ 経済学的な色彩か濃厚であり, district には行政的な色 あいがある。community には社会学で永らく育てられ てきた前歴があって, その体臭がにおってくる。したが $っ て$, 地域栄養計画といらときに, どの「地域」の概念 を用いることが好都合であるか選択せねばならない。す し，政治・経済の視座から地域栄養計画を取りあげるの であれば, region が最もすぐれたすのであろう。たと えば, regional science (地域科学) の立場から論ずるの であれば, community では小さすぎる。しかし，本論 文では, community としての地域を選ぶことにする。 それは，栄着問題を論ずるのには region よりは $\mathrm{com}^{-}$ munity のほうがすぐれているという著者の経験的判断 にもとつくからである゙”。実は region は栄養よりは食 渍になじむといらこともできる。しかし，地城栄盖計画 ではなくて, 地域食糃計画といらときの地域は region や district が適切であろらと思われる。その理由は,

「栄着」が食栕」よりる人間の行動, 心理と深いかかわ りを持った概念であるためと思われる。ちなみに，area はばく然とした地域概念をるっており，これまでどの学 問領域でも専門用語としての取り报いをらけていない。 ただなんとはなく region や district p community を包括する内容の希薄な地理的空間を意味することが多 いようである。

次に，「栄属」の概念については，本誌が栄養の専門

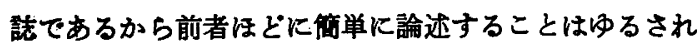

干 113 東京都文京区本郷 7-3-1
ないだろら。したがって本論文をとおしてくり返し論及 することになるが，ここではその梗概を述べることにし よう。

栄養 (nutrition) は栄養素 (nutrients) とは異なるカ テコリリーをっている。通常,「卵には栄着がある」,「栄 養を摄取する」などの表現が日常会話に限らず，学術的 会話や学術論文に用いられているが，卵には nutrition はないし, nutrients は摂取できても nutrition は摄る ことができない。鈴木梅太郎は「‥われわれが適当な食 物を摂って成長し, 生存してゆくことを栄盖といい, こ の食物を栄養素と呼ぶ...」と述へている2)。ここで取り 扱われる「栄養」はまさにこの栄養である。したがっ て, 地域栄養計画は, 地域 (community) の住民が適当 な食物を摄って成長し，生存していくことを理想的かっ 円滑にするための企画である。すなわち，ここで論ぜら れるべき容は地域食䊗計画でるなく，地域一栄羡素-計 画でもないという立場である。

次に, 地域栄養計画は次のステップで検討されなけれ ばならない。

1. 地域栄盖のニードを理解する。

2. 地域栄養の目標を設定する。

3. 地域栄着の方略をたてる。

4. 地域栄養に役立つ資源を収集・整理する。

5. 地域栄盖計画の道具を準備する。

6. 地域栄養計画の評価をする。

以下, この順に項をたてて解説しょう。

\section{2. 地域栄善のニードを理解する}

地域にどのような栄養問題があるかを知ることが, 地 域栄計画の第一歩である。調査地域と調査意四との関 係は 2 とおりあって,一つは地城が先にあって,そこにお ける栄養問題を明らかにするとか，あるいはそれで判明 された栄養問題にどう対処するかを決定するといら場合 
である。この場合, 地域が先行して調査意㘡が後を追っ ている。これに対して他は調查意四が先行して，それに ふさわしい地域を選定する方途である。前者は問題中心 であるが, 後者は研究中心である。地域栄養のニードを 把握することが大切であり, 最む力を入れるのは前者で あることはいらまでるない。

地域の栄養問題を適切な方法で調へてて, 的確に把握し たならば，その後に続く計画の諸段階は大きな過誤を犯 さずにすむので，この第一歩は重要である。地域栄盖の ニードは観念的であるよりは，具体的でなければならな い。そして，それらは多数あってしかむけっして単純な すのではなく，いろいろと錯綜しているはずである。そ れらの具体的なニードを, 初めは整理することなく，ど しどし羅列する。ニードの整理は次のステップの目標設 定につながる。

地域栄養のニードは, 具体的にはどのようなるのがあ がってくるだろらか。数例ほど列挙しょう。

a 、学童の身長・体重が全国平均を下回っている。

b. 平均寿命が短い。

c．経済的に恵まれていない。

d. 偏食が認められる。

e. 貧血患者が多い。

f . 僻地で食品流通が細く乏しい。

g. 労働が苛酷である。とくに農繁期では著しい。

h. 胃がんの症例が多い。

etc.

このよらなことが列挙されたら, 次は地域栄養計画の ねらいの設定に取りかかる。

\section{3. 地域栄碁の目標を設定する}

目標の設定に際して注意しなければいけないことは, 目標には一般目標（general objectives）と個別目標 (specific objectives) とがあることである。正しくは， 目標を一般目標と個別目標とにわけて考えなければなら ないといらべきであろら。一般目標とは相当長期間にわ たる遠大な，本質的なねらいであって，通常これを目的 といって，本来これを objective という言莱にあててい た。個別目標といらのは短期間で到達可能な, 具体的な 枋らいのことで, 通常これを目標といって, 英語の goa 1 をこれに当てていた。つまり，いくつかの個別目標の積 み重㸚をと扎して，一般目標に到達できるるのである。 また別の表現をするならば，一般目標はいくつかの個別 目標によって構成されるとすることすできる。栄養指導 や地域保健活動に打いては，一般目標は決められていて も，個別目標が明らかでないことが多かったようであ る。たとえば，ある町や村で，栄養改善モデル地区を計 画したとしょ5。その場合, 企画者は “第 1 年次の目標
（つまり個別目標）は何ですか?”という問に答えられな いことが多い。そしてか党ってくる答は “貧血をなくす ことです”とか, “脳卒中患者の発生をなくすことです” といら内容のものである。このようなねらいは個別目標 の範䁣にははいらず，一般目標のそれである。

いま仮に脳卒中（脳血管障害）患者の発生をなくすこ とを一般目標と決定するならば，その一般目標を達成す るために，いくつかの個別目標が設定される。

栄盖に限定すると

1）食塩攝取の制限（cf. 地域栄着ニードとして食塩 の過剩な摂取があると認められるとき）

2）海藻類の摂取量の増加（cf. 地域栄養ニードとし て海藻類の摂取不足があると認められるとき）

3） * 野菜類の摄取量の增加（cf. 地域栄養ニードとし て野菜類の摂取不足があると認められるとき）

などが挙げられるだろら。そして，この 1)〜3）の個別 目標はできることならぱ，もっと具体的に示されねばな らない。たとえば,“3）冬季または端界期における野菜

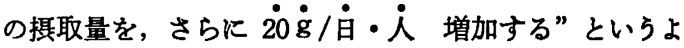
らに，ねらいをきちんとすることが，後でその計画を具 体的に評価するために必要である。

一般に，地域を対象とする研究は，実験 (experiment) や試験（trial）であるよりは調查 (survey) であることが 多い。実験は条件設定が敩密で，それたけとその条件設 定をきちんとそろえれば実験の再現性はきわめて高い。 しかし，調查は条件設定が緩やかであり，ために再現性 は乏しい。そのような調査になじむうちに，いつのまに か慢然とした計画をたて，不完全な調査を実施し，その 成果の評価は不十分なままに放置される傾向がある。地 域栄養計画です，その欠点を払武できないことが多い。 これを是正するためには，目標を上述のごとく設定しな ければならない。なお，目標設定は基本的には以下のこ とを充足するとよい。

1）目標は実際的なるのである。

2）目標は地域住民にも，実務担当者にも理解でき る。

3）目標はその達成状況が測定できるるのである。

4）目標は行動の变容を含む（ただ “知っている”と いらものであってはならない)。

5）目標は達成できるものである。

\section{4. 地域栄養の方略をたてる}

方略 strategy はいわゆる大局的な手順のことであり， こまかい具体的な手順ではない。このような方略を地域 栄養計画に関してたてることは，やはり個々の例におい て異なるので, 先にあげた脳卒中患者の発生をなくすこ とを一般目標とした方略を考えることにしよう。 
方略は一般目標と個別目僄（ここでは先述の 1) 3） をらけることにする）に対応してつくられる。

方略 1. 対象地域の食物摄取量の実態を把握する。

方略 2. 食習慣（食制, 食具などを中心に）をリスト アップし，その地域の伝较に由来する特色を把握する。

方略 3. 食品流通の機構を調查し, その実態を流れ困 としめす。

方略 4. 食物・料理に関する意識調査を実施して, 栄 盖知識と食生活改善への意欲とを推し測る。

方略 5. 同地域を所轄する保健所, 地方自治体（市・ 町・村と県) に働きかけて協力事業となるように community organize する。

このような5 項目をあげたが，それは必ずこうでなけ ればならないといらのではない。特定の地域が対象とし て与えられるならば，さらに具体的なものになるだろ う。また，高血圧症の患者を減らすためには，むっと他 になすべきことがあるといら立場があるから，そのため にも変更が起こってしかるぺきであろら。

この方略に関してとくに強調せねばならないことは, 食塩摄取量の減量や, 海藻・野菜類の摄り方の適正化を はかるなどの個別目標に到達するためには, 食習慣, 食 品流通，赀好などの地域特性を踏まえて，包括的に取り 組む必要があることであって, 個別目標の標的たけをを個 々に取りあげて,「改めろ! 改善しろ!」といらのではい けないということである。

\section{次に，各方略について説明しょう。}

方略 1 : 食物摄取状況を把握することは, 対象地域の 食生活に関する偏見や憶測による予断を除くためにる， 適正なサンプル数を整えなければならない。これは, 時 にはすでに地域栄着ニードを収拾する段階で済まされる ことがあるが，そのときは改めて，ここでくり返す必要 がない。その場合でる，その資料を目標に沿って詳しく 統計的に分析する必要があるだろう。たとえば，食物消 費構造, 集団凝集力, 世帯間類似度, および世帯業態別 の食物消費の特性, 世帯の構成人員数にもとづく食生 活上の特徵, 家計支出額と食生活との関係など, すでに 開発されているいろいろな分析方法によって, 対象地域 の食生活上の特性をできるだけ多くの属性に関して分析 し，検討することが望ましい。

方略 2 : 食生活が長い歷史的背景をむっていること, また, 比較的に小さな地域モザイク性をるって営まれて いることがわかっている。したがって, 食生活を变革さ せるためにはそれらの点に関する考察を通して, 具体的 な接近方法を採用しなければならない。

方略 3 : 食品流通が実は自然環境の制約を越えて食生 活が営まれるための有力な要因であるから, 食品流通の 状態については今まで以上に注意を払わねばならない。
小売店に陳列されている食品は，ただたんに“供給”の 実態としてみるべきではなく，“需要”があるからこそ 仕入れられているので, そこに需要の襄側にある食生活 の実態をみることができる。したがって，生活の経済的 な側面としての意義だけではなく，食生活的側面を十分 に具現している。地域栄着の視点でこれを軽視すること はできない。

方略 $4:$ 意識調查は過去の食生活についての記憶と, “かくありたい”という意見とが入り混ったものを汲みと ることができる。記憶は食生活の Sein (存在) 的側面を, 意見はその Sollen (当為) 的側面を形成している。もし， 意識調査を質問票で実施するのであれば，質問項目の文 言を記憶または意見にはっきりと焦点をあわせてっくれ ばそそれぞれの純度の高い回答が得られるだろう。記憶 に焦点をあわせたのであれば，過去の食生活を窥い知る ことができ，意見に焦点をあわせたのであれば，未来の 食生活の方向を推測することができる。食習慣が過去の 食生活の上に成り立つむのであるといえるので，それは 方略 2 で一応汲み取るとして, ここでは未来の食生活を 模索するといら意味で, 意見ないしたてま兄としての食 生活を汲及取るのが主たるねらいになるだろら。

方略 5 : 地域栄養計画の中で最も栄養より遠い, どち らかといらと行政的な問題をここにまとめている。しか も最も肝心なことであると考えられて, 従来から地域栄 養で重要視してきたことはきわめて正しいといえよう。 しかし,方略 1〜4までを抜きにした community organization は所詮実効を伴わないものであったことは反省 しなければならない。

\section{5. 地域栄養に役立つ資源を収集・整理する}

地域栄養に関連する文献や人材を収集することはたい せつでありながら, 実際にはなかなか困難なことであ る。文献や資料を集めることは学者や研究者にはそれは ど難しいことではなくても, 実務家にとってはそらでは ない。集められた資料を整理することは学者や研究者に とってる困難であって, 平素の努力を必要とする。ま た，地域を対象とする研究資料や報告(行政報告を含む) は多岐にわたり, 該当する適切なるのが少ない欠点があ るが, 地域栄養計画が弱いのは, むしろすでに述べた調 査 (survey) が実験 (experiment) などに厥密な条件設 定ができないために，該地域の条件に合った既資料をみ いたしえがたいことに起因する。すなわち，実験室内に 怙将る, 精密機器・手技・操作手順・試薬・温度・濃渡 ・ $\mathrm{pH}$ ・純系動物などをさちんと揃えて実施できる実験 と，人権を損わぬように，生活を冒さぬようにおそるお そる実施する調查との間にある本質的な相違は，その資 料の内容が多岐にわたることではないことは確かであ 
る。しかし，資料が多岐にわたることを無視することは 正しくないので，以下にどのような資料があるかを簡単 に例として举げることにしよう。

A. 文 献

1）網目の大きい情報（国レベル〜県レベルの単位の 情報)

（）各種白書（厚生白書，国民生活白書，農業白書， 漁業白書, 経済白書など)

(b)厚生省関保のおむな統計（国民栄着の現状，伝染 ，病打よび食中毒統計，国民生活実態報告，保健所報 、告, 病院報告)

(C農林省関係の括むな統計（農民栄養統計，食糧需 給表など）

(1)総理府統計局関係のおむな統計（家計調查年報， 全国物価統計調査報告など)

(eWHO・FAO のおむな統計 (Demographic Year Book, Production Year Book など)

2）網目の比較的こまかい情報（県レベル〜市町村レ ベルの単位の情報)

該当地域に直接関係をもつ情報はこのレベルより小さ い単位の資料から得られることが多い。

（定期的に刊行されている資料 $\mathrm{i}$ 県勢要覧, 市・町・村勢要覧 ii 保健所年報

iii各種の地方自治体広報資料

iv 雑誌（栄着，公衆衛生の專門誌など）

(b)不定期刊行物

$\mathrm{i}$ 単行本（これは狭い栄盖関係出版物に限定しな いで，厷く民俗学，人類生態学，文化人類学の論著 や，社会，経済，農業経済，および地方誌，食品衛 生関係出版物を含む)

ii 社会・消費者調查の報告書（マーケッティング 調査の報告書や各食品工業関係者が出している消費 生産に関する調査報告書を含む)

\section{B. 人材}

人材は公的な専門家（栄養・保健の専門家，その他の 専門家) や，私的な專門家（料理学校，料理の好きな人 で尃門家としての識見のある人に限らず経済人や市町村 議員の中からも求めることができる）などを選び，有能 な人材をリスト・アップする。そしてこれらの人の協力 を得るように慎重に配虑する。それは，専門家の間の専 門家であるがゆ兄の対立に対する配慮たけではなく，影 敕力の強い人たちなのですくなくとも敵にまわさないよ らにすることも含まれる。

一般的にいって，もし，資格を問わないならば栄堆問 題に関する人材は多すぎてその間の調整に困っても不足 することはないはずである。

\section{6. 地域栄誉計画の道具を準備する}

地域栄盖計画の道具・器材は, キッチン・カー,クッ キング・ルーム・有線などから，パンフレットK至るま で大道具・小道具いろいろある。それらは栄養指導のた めの機器としてすでによく知られている。あるいは，学 校の教材として利用されているものを頭に浮べとよ い。視聴覚教育の器材はすべて,ここに利用できるるの であるが，そのほか，味覚や嗅覚・触覚などありとあら ゆるものを利用できると心に思い決めることが肝心であ ろう。

\section{7. 地域栄萎計画の評価をする}

評価をする前に, 計画実施の段階があるが，これは， 目標，方略にもとつう，資源として道具を活用して実施 されるがここでそれを具体的に説明することは避ける。

さて，評価は全体についてなされるか，それは計画実 施の成果の評価にあたる。また，各ステップについても 個々に評価しなければならない。実施した結果, ニード の肘度について，目標設定について，方略，資源につい て, また具体的に用いた機器の選択と使用方法について 反省される何かがあるはずである。その反省は次回の二 一ド把握や目標設定以後の各段階に必ず活かされるであ ろう。評価は，目標設定が具体的であるほど，また測定 可能なるのであるほど，また目標の何たるかを理解でき るものほど正確に，かつ客観的に判定される。そして， 到達可能な目標であれば,この地域栄養計画は評価され， この計画に参与したものの意欲を高めるものとなるだろ う。また，地域住民の知識向上たけではなく，行動の変 容をねらったものほど，その栄養計画は実効を伴らすの となるたろら（参照：2. 地域栄養の目標を設定する)。

また，目標設定で一般目標だけにとどまったり，ある いは個別目標のねらいが大きかったり，観念的であった りすれば評価は十分にできないであろう。一般目標は長 期間にわたる理想的なねらいであるから，容易に到達で きないだららし，また強引に評価しようとしても，一般 目標を分母とし，到達した段階を分子とする到達度は， 分母が大きくて商は常に小さな值に落ちつくからである （注： $\frac{\text { 到達値 }}{\text { 一般目標 }} \risingdotseq \frac{\text { 到達値 }}{\infty}=0$ )。

このようなときは，目標設定が厳しく批判されねばな らない。もら少しくわしく説明すると，いまもし脳卒中 患者発生数を0（ゼロ）にすることを個別目標に設定す れば，どう努力してもすでに前段階にまで来ている人は 必ずいて，その人が毎年少しずつ発症して，この計画は けっして高い評価をうけないだろら。ここで，先述の 3）*を例にとって具体的に $20 \mathrm{~g}$ 增加を個別目標とすれ ば，たとえば野菜類の摄取量が $15 \mathrm{~g} /$ 日・人しか増加し 
なかったとしてる，個別目標の $20 \mathrm{~g}$ /日・人に対して， 75\% の到達度であると評価できるであろう。そのこと自 体はすぐには脳卒中発症をなくすことにはならないが， 臨床病理や栄養生理学の知見が正しければ, 必ずや将来 にはその一般目標に近つ’くであろう。そして，次回の栄 養計画では $75 \%$ よりも高い段階へ到達するための励及 にもなると思われる。

このように具体的に評価ができれば，その栄養計画は 到達率が $100 \%$ でなくても十分に評価されるるのとい兄 よう。具体的評価ができない場合は，地域栄養計画とし ては失敗に終わったことになる。これはすこし苛酷な言 回しと思われるかるしれないか，栄盖士は自己の活動に 自信が持てなくなるだろう。部外者が栄養指導ないし栄 養改善はあまり意義がないと批判する以上，けっして栄 盖士は自分を甘やかしてはいけない。

さて，以上述へててきた地域栄養計画を模式図で示すと 図1のような円錐台であらわすことができる。ちょらど 榑または桶をさかさにおいた状態であって，榑の木に相 当する 6 段階のチェック・ポイントがあって，それをき ちんと締めつけるような膂(たが)として, 第 1 次個別目 標, 第 2 次個別目標が描かれている。これらはそれぞれ 第 1 年次, 第 2 年次の個別目標のことである。因 1 を注 意深く見ると地域栄養計画の進捗状況は第 1 次, 第 2 次 個別目標に到達していないように描かれている。これ は、ただ，多くの計画が目標の到達できないことを踏まえ て，そのように描かれている進捗状況の矢印が螺線状に 上昇していくが，それが理想的な一般目標に到達できな いことも示すために，この模型が円錐ではなく円錐台に なっている。また全体を統一する考方方 (philosophy) が あって，これが䇥をきめるときの基本的姿勢になる。統 一的な，あるいは一貫した考え方がないときは筷が不揃 いになって，榑はゆるんでしまう。したがって地域栄盖 計画にとって最も基本的なことは，この統一的な，ある いは一貫した考え方をまず守ることであろう。

\section{8. まと め}

このような統一的な, あるいは一貫した考え方は世界 観といらこともできるし，健康観といらこともできる。 地域栄養計画に打りる世界観ないし健康観の中心は栄盖 学概論である。ここで概論が問われている栄養学は, 栄 養素だけが注目されるのではなく，また栄養障害だけが 論じられるのですなく，料理・調理の方法たけが問題な のであなく，また食糔生産たけであなく、ひろく食の行 動をす含む広義の栄荃でなければならない3い。食とは すくなくとも「食は多数の調理食物 (Speise) より成り, 調理食物は一つ以上の食物 (Nahrungsmittel) を含み, 食物には数種の食素（Nahrungsstoff）を含んでいる…」

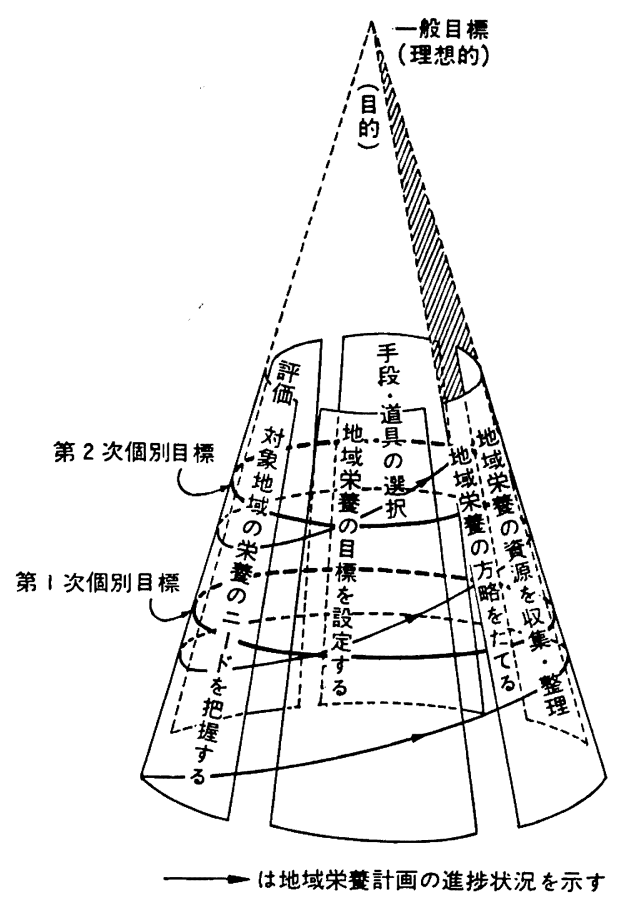

図 1. 地域栄養計画の模式図

と森鷗外が説明した食のことであるといえる。しかし， さらにこのような食 (Nahrung) を営む社会的・心理的, かつまた自然環境的な要因をも添えた広い意味での食で なければならない。このような広義の食を取り扱らこと は，とりもなおさず公衆栄養の視座に立つ栄養計画であ るら。栄湌士養成カリキュラムに新しく市民権を得たこ の公采栄養の視座は, 要約すると次のようなるのである。

(1) 人類生態学とりわけ人間の食生態学に関連する

（2）生理学・生化学的に究明された，すぐれて分析論 的な栄養学の基盤に立っている

（3）食品衛生学 (food hygiene) と公衆衛生（public health) と地域医療 (community medicine) の医学的 基碟に立っている

（4）食糧生産, 食品流通などの農業経済的視点をるっ ている

（5）その他多くの関連領域に対する接触があって, そ れらを包括的に統合する

などである。

このような地域栄養計画は実施不可能だとする人るい るだろらが，比較的に小さな地域集団ならば可能であ る。今後, 栄養問題が明らかに認められる地域小集団を まず手はじめにこの地域栄養計画を試み, その知見を䆅 み重ねて徐々に大きな地域栄養計画を実施することが望 ましい。 
文献

1) 豊川裕之：公衆柴善 (1976), 光生館, 東京

2) 豊川裕之: 食生活之健康 (1975), 大修館, 東京

3）豊川裕之：蛋白食料問題の栄盖学的検討, 食生活 研究部会報告書 (福井忠孝班長), 厚生省公衆衛 生局栄盖課 (1975)
4）豊川裕之：計青的食生態学, 食生活研究（細谷害 政，铃木継美 編著)，(1975)，第一出版，東京

5）細谷密政:日本の栄产計画 (政策) の経過, 栄秦 之食糧, 28, 468 471，1975.

(昭和 51 年 1 月 19 日受理) 